\title{
LA DIFÍCIL NACIONALIZACIÓN DE LA DERECHA ESPAÑOLA EN LA PRIMERA MITAD DEL SIGLO XIX
}

\author{
por \\ JOSÉ ÁLVAREZ JUNCO \\ Facultad de Ciencias Políticas y Sociológicas \\ Universidad Coplutense de Madrid
}

RESUMEN: Se describe en este artículo la evolución de la opinión conservadora española a lo largo de la primera mitad del siglo XIX en relación con el surgimiento del nacionalismo. Al principio, la nueva formulación de la legitimidad política en términos nacionales no fue bien recibida en los medios conservadores. La procedencia revolucionaria de la teoría de la soberanía nacional resultaba sospechosa para quienes estaban acostumbrados a justificar la obediencia al poder en términos religiosos y de legitimidad dinástica. Hacia la cuarta o quinta década del siglo, en plena moda romántica y bajo la influencia del pensamiento de Balmes, la opinión católica comenzó a aceptar la nueva visión del mundo en términos nacionales, siempre que se identificara estrictamente "España» con el catolicismo.

Palabras clave: Nacionalismo. España. Catolicismo. Conservadurismo. Siglo XIX. Historiadores.

ABSTRACT: The article describes the evolution of Spanish conservative opinion throughout the first balf of the nineteenth century, with regard to the rise of nationalism. At first, the new formulation of political legitimacy in nationalist terms was not well received in conservative circles. The revolutionary origins of the theory of national sovereignty was suspect for those who were accustomed to justifying obedience to power in terms of religion and dynastic legitimacy. Around the fourth or fifth decade of the century, in the apogee of Romanticism, and under the influence of Jaume Balmes, Catholic opinion began to accept the new world view in terms of national identities, as long as "Spain» was strictly identified with Catbolicism.

KEY WORDS: Nationalism. Spain. Catholicism. Conservatism. Nineteenth-Century. Historians. 
Los gritos que recorrían la Andalucía sublevada en 1808, según el capuchino Rafael de Vélez, eran «iViva María Santísima, viva Jesucristo, viva su fe, su religión, viva Fernando VII, mueran los franceses!». No por provenir de un fraile parece que peque el testimonio de parcial. Muchos otros confirman que los rebeldes contra José Bonaparte en aquel agitado verano vitoreaban, sobre todo, al catolicismo y sus dogmas; con más fervor quizás, pero, desde luego, menos veces, se invocaba al deseado monarca; y se olvidaba, con frecuencia, o aparecía muy en último lugar, a la nación. El «grito de la nación», lo llama precisamente fray Simón López, que «resonó por todas partes», pero dice que su contenido era: "viva la religión, viva la Iglesia, viva la Virgen, viva Dios, viva Fernando Séptimo, muera Napoleón, mueran los franceses»; poco más adelante repetía la retahila, con leves variaciones: «Viva Fernando VII, viva la Religión, viva la Iglesia Católica y muera Napoleón impío con todos sus satélites y su Francia cismática, tolerante, anti-cristiana». La nación, como se ve, contrariando sus más arraigadas tendencias, no se vitoreaba a sí misma, sino a su rey y, sobre todo, a las creencias religiosas colectivas y la institución eclesial que las encarnaba. Un par de décadas después de aquella guerra, un tercer clérigo, fray Manuel Amado, sintetizó muy bien la idea: «No fue cuanto hicimos en favor de nuestra patria; obramos porque la religión exigía de nosotros que obrásemos de ese modo» ${ }^{1}$.

Todos los observadores, empezando por los generales franceses y hasta por el propio emperador, coincidieron en atribuir al clero católico el papel protagonista en la movilización anti-napoleónica española. No hay la menor duda de que el deber ciudadano de combatir al invasor se fundamentó, para la gran mayoría de los combatientes, en la doctrina católica. Entre los héroes y símbolos invocados en la lucha, con mucha mayor frecuencia que Pelayo, El Cid o Hernán Cortés, figuraron el apóstol Santiago o las vírgenes patronas de la zona: la de Covadonga en Asturias, la Fuencisla en Segovia, la del Pilar en Zaragoza... Incluso las referencias a la patria solían cualificar el término añadiéndole «sus antiguas costumbres» o «sus sacras tradiciones»; entre las cuales figuraba siempre en primerísimo lugar la religión católica. España y el catolicismo eran, en la mayoría de las mentes, una misma cosa ${ }^{2}$.

\footnotetext{
1 VÉLEZ, Rafael: Preservativo contra la irreligión, Cádiz, 1812, p. 116. LóPEZ, Simón: Despertador Cristiano-Político, Valencia, 1809, pp. 17 y 18. AmAdo, Manuel: Dios y España: o sea, Ensayo sobre una demostración bistórica de lo que debe España a la Religión Católica, Madrid, 1831, vol. III, p. 261.

2 Para Napoleón, fue una «revuelta de frailes» (NÜRNBERGER, Richard, cit. por GonZÁlez Cuevas, Pedro C.: Historia de las derechas españolas, Madrid, 2000, p. 67) y es sabido que durante su estancia en España, en diciembre de 1808, decretó la abolición de la Inquisición y la reducción del número de conventos en un tercio. El propio padre Vélez escribe que «los clérigos y los frailes sostuvieron con energía nuestro odio a la Francia» (cit. por HerRero, Javier, Los orígenes del pensamiento reaccionario español, Madrid, 1971, p. 312). Para dichas invocaciones, v. GUERRA, François-Xavier: Modernidad e Independencias, Madrid, 1992, p. 158.
} 
Esta identificación iba a mantenerse largo tiempo todavía; de forma indiscutida, como mínimo toda la primera mitad del siglo XIX. Pero - y esto es lo que aquí interesa - tal supervivencia se mantuvo, si no en contra, sí relativamente al margen del mito nacional, que era en aquellas décadas iniciales de la era contemporánea monopolio de los liberales. Pues la idea de nación llevaba en germen una legitimación laica, autónoma, del Estado, cosa, en principio, poco grata a oídos eclesiásticos, como eran los de casi todos los ideólogos del conservadurismo hispano del momento. Sólo a medida que avanzó el siglo comenzaron a fundarse las elaboraciones doctrinales de los núcleos conservadores en los mitos nacionales. El objeto de este capítulo consiste precisamente en describir tal evolución, es decir, la forma en que esos círculos conservadores, que se definían más por su religiosidad que por su adhesión al Estado, se fueron haciendo nacionalistas. Para describirlo de una manera gráfica, no hay más que reparar en el hecho de que, en la guerra carlista de los años 1830, a las tropas isabelinas o liberales se les aplicaba el adjetivo de «nacionales», frente a sus enemigos carlistas, «absolutistas» o «apostólicos». Exactamente cien años después, en otra guerra civil no menos terrible, quienes se autocalificarían como «nacionales» serían los conservadores, los herederos del carlismo anti-liberal. El cambio de adscripción de la referencia nacional entre esas dos guerras civiles sintetiza la evolución que intentaremos seguir en este capítulo ${ }^{3}$. Adelantemos desde ahora mismo que este proceso de nacionalización de la opinión conservadora se llevaría a cabo gracias a la fusión de la identidad española con el catolicismo; o, puestos a ser precisos, gracias a la fusión de una de las interpretaciones en conflicto sobre la identidad española: la que más adelante, ya en el siglo XX, habría de recibir, precisamente, el nombre de nacional-catolicismo. Dado que el catolicismo será una constante del conservadurismo español, desde su fase prenacional hasta su fase nacional-católica, y aun sabiendo que no todo el catolicismo era ni es necesariamente conservador, usaremos, a lo largo de este artículo, casi como equivalentes «opinión conservadora» y «derecha católica».

La concepción de la realidad social y política de comienzos del siglo XIX por parte de la derecha pre-nacional española se basaba en una versión mitificada del pasado humano no muy distinta de lo que se conocía, por aquel entonces, como «Historia Sagrada», una historia de la Iglesia católica engarzada en el relato bíblico. Es esta historia la que se proyecta sobre la política contemporánea, y en particular sobre la situación española. Para ello podría servirnos cualquiera de los autores mencionados: Ceballos, Hervás y Panduro, Diego de

3 Uso del término «nacionales», referido a las tropas cristinas, p. ej., en los Episodios Nacionales, de Benito PÉreZ GaLdós: en Luchana, cap. XXVI; o en La campaña del Maestrazgo, caps. III y VII, al relatar el fusilamiento de la madre de Cabrera («los nacionales negábanse a cumplir la sentencia»; «los nacionales trinaban y creían que se habían deshonrado»). A finales de la década de los 1830 fue cambiando el significado y «nacionales» se usaba para referirse a la Milicia Nacional, v. Los Ayacuchos, caps. XXV y XXVI, tiros entre «nacionales» y soldados, o referencias a la ceguera de los pobres «nacionales» en la Barcelona insurrecta en 1842. 
Cádiz, Simón López o Vélez. Pero utilizaremos con preferencia los textos de $E l$ Filósofo Rancio, fray Francisco Alvarado, polemista célebre durante los años de las constituyentes gaditanas, porque sintetizó la herencia de todos ellos.

El punto de partida de esta visión del mundo es del más sencillo maniqueísmo: hay una lucha universal y eterna entre dos principios, Bien y Mal, representados por la Iglesia, portadora de la verdad revelada, y Satanás, que no pierde ocasión de azuzar la rebeldía humana. De las sucesivas encarnaciones de esta rebeldía, es especialmente interesante la que, en siglos recientes, ha tomado la forma de racionalismo filosófico. Y hay que aclarar que se considera racionalista a todo el que utiliza la razón o hace filosofía al margen del magisterio eclesiástico, lo cual encubre, como observa José Luis Abellán, "no sólo un rechazo de los principios esenciales de la Ilustración y el liberalismo, sino de toda la filosofía en general»; Alvarado, en efecto, escribe que "apenas apareció el Evangelio en el mundo, luego desapareció toda otra filosofía; [...] él sólo era el que contenía la verdadera» ${ }^{4}$. Este es un punto que merece ser desarrollado. Ya desde Hervás y Panduro se sabía que los enemigos de la Iglesia no eran sólo los protestantes, sino también «los filósofos». También Vélez había denunciado como objetivo oculto de la «filosofía» la destrucción de religión y tronos, para devolver a los hombres al libertinaje y la anarquía, y había dado a la luz el nombre del «jefe de los filósofos»: Voltaire. Pero nadie era tan directo como Alvarado: para él, el mundo se dividía entre fuerzas del bien y del mal y entre las primeras incluía a «rey, pares, nobleza, monarquía absoluta, títulos, papa, obispos, curas, católicos, ricos»; lista un tanto impúdica de los poderosos de la tierra, pero no sorprendente; mas al describir las fuerzas del mal sí sorprendía Alvarado, pues sólo incidentalmente hacía referencia a algún tipo de jerarquía social o lucha de clases (por ejemplo, cuando escribe que las modernas declamaciones en favor de los «derechos humanos» no son sino ataques encubiertos de los pobres cobardes que intentan robar a los ricos las justas posesiones que les entregó la Providencia). A quienes detesta Alvarado de verdad y denuncia sin cesar es a los «abogadillos de agua dulce», «los llamados publicistas», los «corbatas, oficialillos, caballeros pobres, ricos entrampados, clérigos arrepentidos, abates de becoquin y pantalón...» $\aleph^{5}$. Lo que puede deducirse de esta obsesión con intelectuales y profesionales independientes es que los problemas de la religión en el mundo moderno no le parecen al buen fraile relacionados con pugnas sociales - entre burguesía y nobleza, o entre pobres y ricos-, sino con

4 Abellán, José Luis: Historia crítica del pensamiento..., IV, p. 173. Alvarado, Francisco: Cartas críticas que escribió (...) El Filósofo Rancio, Madrid, 1824-1825, vol. I, p. 34. Al igual que Vélez, Alvarado insiste, en su vol. V, en el eterno conflicto entre el Evangelio y la filosofía; Vélez añade que esta última, además de diabólica, es femenina; Alvarado se permite burlarse de Aristóteles.

5 Alvarado: Cartas..., cit., II, pp. 383-4; cfr. I, p. 60: «abogadillo de la nueva extracción», «clérigo petimetre», «corbata erudito a la violeta»...; III, p. 126: «señores oficinistas, covachuelos, oidores, abogados», y p. 185: «zánganos encargados en la intervención y recaudación, papelistas, oficinistas y demás gente non sancta». 
la rivalidad entre la intelectualidad emergente y el clero. Así lo vivía, al menos, este sector ultraconservador del clero.

Visto de esta manera, es decir, identificando pensamiento independiente con racionalismo y rebeldía, se comprende que se considere figura eminente del racionalismo a un fideísta tan notorio como Lutero; o que se coloque entre las huestes racionalistas y ateas a un deísta sentimental, pre-romántico, como Rousseau. ¿Y qué decir de los pobres jansenistas, ni racionalistas ni ateos desde cualquier perspectiva que se consideren, pero dispuestos a aceptar ciertos derechos regalistas frente a la Iglesia? «Eclesiásticos liberales», los llama Alvarado, "otra casta de pájaros [...] tan malos como los filósofos o peores», porque se empieza por jansenista y se acaba en ateo; son herejes, y la herejía es «hermana de la sedición». Su delito, en definitiva, fue haberse rebelado contra Roma, haber apoyado los derechos del rey frente a la Iglesia, cosa tanto más grave cuanto que se trata de eclesiásticos. Se entiende también así que Alvarado equipare la actitud de los «filósofos» de su tiempo —es decir, los liberales gaditanosfrente a Fernando VII con la de los comuneros frente a Carlos V. La osadía, la ambición y el deseo de venganza movieron por igual a unos y a otros. iHasta habían coincidido los dos en pretender cargar a los nobles con impuestos! Ambos se habían movido por impulsos perversos, como la envidia, la lascivia o la soberbia. Los constitucionalistas gaditanos formaban parte, en definitiva, de «una conspiración [...] contra Dios y contra su Cristo»; su objetivo era «abolir la religión» para dejar que se expandieran sin freno las pasiones humanas ${ }^{6}$.

Otro aspecto destacable de esta visión de la historia es la obsesión paranoica con los métodos clandestinos de los perversos. No debería extrañar que en el mundo de las monarquías absolutas, en que la oposición política no podía actuar en libertad, ésta recurriera al secreto. Pero, para los ideólogos contrarrevolucionarios, ese secretismo del enemigo probaba sus connivencias demoníacas. Hervás o Vélez, de nuevo, se habían adelantado denunciando la «conjuración universal» de los filósofos, inspirados por Satanás, contra «todos los tronos y toda religión». Alvarado ratifica: como los protestantes fracasaron en España, «mudaron de sistema. Lo que antes nos decían como teólogos, nos lo empezaron a decir en tono de filósofos y publicistas»; pero su plan -insiste- es «atacar la religión de Jesucristo» o incluso «echar por tierra toda religión». Quiénes sean los agentes específicos que han entrado en esta conjura, es asunto adaptable a las preferencias o imaginación de cada autor: el abate francés Agustín de Barruel, el primer gran fustigador católico de la Revolución francesa, estableció, en sus Memorias para servir a la historia del jacobinismo, la versión canónica de

6 Alvarado: Cartas..., I, pp. 37 y 329; dedica a los jansenistas la práctica totalidad del segundo volumen, pp. 46-306; cfr. I, p. 88: «el famoso Erasmo, de quien con tanta razón se dijo que había puesto los huevos que Lutero empollaba»; liberales como comuneros, en I, pp. 148-149; liberales gaditanos, ateos, en II, p. 451. Comparación de las «depravaciones» de los liberales con las de los comuneros, también en el folleto Los verdaderos españoles residentes en Cádiz..., Cádiz, s. d. (circa 1816-18) 
cuatro sectas demoníacas coaligadas: filósofos, francmasones, iluministas y jacobinos; con Voltaire y Federico de Prusia como fundadores de la conspiración, apoyados por la Pompadour, que veía en el clero un obstáculo para sus inmorales amores. Antes que él, Hervás y Panduro había enumerado también cuatro sectas, aunque la fecha de su obra no le había permitido incluir a los jacobinos y ocupaban su lugar los jansenistas. Alvarado ratificaría las cuatro organizaciones malignas, las mismas que Barruel, con el añadido de que, en España, el ejemplo supremo de la inmoralidad había sido Godoy, él mismo parte de la conspiración de los jansenistas, apoyado por filósofos que habrían participado en sus orgías?

Ante tan dramática situación, con las creencias religiosas y la autoridad política asediadas y a punto de ser derrotadas por un conjunto de sectas malignas, ¿qué podía hacerse? Las soluciones ofrecidas por estos ideólogos no suelen ser sutiles. La primera, apuntada sin demasiada esperanza, es el conformismo, la sumisión voluntaria a las superioridades justas, el control de las pasiones por medio de una conciencia moral firme y, en especial, la represión de esa soberbia que nos lleva a creer posible un mundo basado en la razón y la libertad. Pero si la auto-represión no funcionaba - y en los últimos siglos era obvio que no funcionaba-, sería inevitable recurrir a la represión externa, violenta, a cargo de la autoridad pública, guiada por la Iglesia. Alvarado no duda de que los filósofos, «raza maldita», vanidosos y pecadores, que aparentan religiosidad pero son ateos, merecen ser exterminados. Frente a ellos debe actuar la Inquisición, como lo hizo ante el peligro judío y musulmán, con «toda la severidad y rigor que por necesidad se usó a fines del siglo XV y principios del XVI. Apestaban entonces la nación los que del judaismo y mahometismo se fingían cristianos [...] La apestan ahora los filósofos y francmasones que se cubren con el nombre de católicos [...] con el designio de abolir toda religión y apoderarse de todos los imperios». Alvarado dedica largas páginas a justificar el uso de la violencia, que no contradice la mansedumbre cristiana - «la santa crueldad», lo llama Javier Herrero-, y ensalza sin reparos a la Inquisición, un tribunal que, si inflige dolor a los perversos, protege a los justos de los sufrimientos derivados de la anarquía. En España, la Inquisición ha conservado, durante siglos, «la paz, la unión y religión sobre la que se funda toda buena república»; ha sido «antemural de su fe y seguro garante de su paz", y sigue siendo el único baluarte que puede defender esa unidad católica que la Constitución liberal reconoce pero que los liberales,

7 Alvarado: Cartas..., I, pp. 89 y 268 y ss.; II, 442 y 469; cita, en III, 125, en p. 135, más depravación de filósofos; cuatro sectas, en I, 270; filósofos, unidos con Napoleón, cumpliendo el plan de Voltaire y Federico de Prusia para acabar con la Iglesia, en III, 416-421. HeRvás y PANDURO, Lorenzo: Las Causas de la revolución francesa...: calvinistas, filósofos, jansenistas y masones, las 4 sectas; calvinistas, especiales amantes de la inmoral libertad; de ellos vienen directamente los jansenistas, que se disfrazan de católicos. La obra de Barruel se tituló Mémoires pour servir a l'bistoire du Jacobinisme y fue publicada en Londres en 1798, en el exilio, simultáneamente en francés e inglés (v. HERRERO, Javier: Los orígenes del pensamiento..., p. 193). 
en el fondo, no desean. No es extraño que el Santo Oficio sea el «ídolo de toda la nación", porque «este pueblo sabe que la Inquisición no es la religión; pero [...] quitar la Inquisición es una medida que va a dejarle sin religión» ${ }^{8}$.

No hay mucho más. Todo se resuelve en una defensa del statu quo a ultranza. La unión entre política y religión, el propio carácter sagrado del orden social, lo convierte en inmutable. Una mera alusión a "reformar» algo es sospechosa. Especialmente intolerable es la idea de pacto social, que supone la posibilidad de que las sociedades decidan por sí solas su forma de organización política. "Dios es el autor de la sociedad, y no el pacto de Rousseau». Los verdaderos principios políticos, dice Alvarado, están en el Evangelio, pues no hay más libertad, igualdad o dignidad humana que las derivadas de ser «hijos de Dios». De todos modos, hablar de libertad o igualdad es peligroso, pues podrían creerse bases naturales de la organización social, cuando el orden natural es, precisamente, desigual y coactivo: «iserán iguales por naturaleza los hombres, entre quienes por su misma constitución natural unos mandan y otros deben obedecer? [...] La igualdad por naturaleza que nos presentan estos señores filósofos es un sueño, y sueño de un frenético [...] La religión nos enseña todo lo contrario [...] Vemos padres e hijos, y solamente el infame autor de los iluminados ha sido capaz de intentar que los hijos sacudan esta dependencia de la naturaleza». La desigualdad y la pobreza son fenómenos queridos por Dios, que hizo una "sabia distribución» en el mundo, de forma que «unos abunden y a otros todo les haga falta». La nobleza es especialmente necesaria, pues «un Estado sin nobles es un cuerpo sin manos", dice Alvarado, parafraseando al obispo Guevara. El tejido social es jerárquico, al igual que el familiar, y los reyes ejercen la autoridad sobre sus pueblos como los padres sobre sus hijos. Más aún: los reyes actuales descienden de los antiguos patriarcas bíblicos, a quienes les confirió el poder directamente Dios. Su autoridad es absoluta, aunque Alvarado y los demás escritores de su línea maticen habitualmente que eso no la convierte en caprichosa ni despótica, pues está sometida a unas «leyes tradicionales» y a la moral cristiana; como las primeras siempre quedan en la inconcreción, es la última, en definitiva, la única que tiene alguna efectividad, pues alude a la vigilancia suprema de la Iglesia sobre el poder civil9.

8 Herrero, J.: Los orígenes del pensamiento..., p. 393. Alvarado, F.: Cartas..., II, p. 469 (cfr. I, 37); La Inquisición preserva la paz, en I, 267; cfr. I, 121 (el señor Argüelles «va a sumergirnos a todos en un abismo insondable de males. A la libertad de conciencia se sigue la de dogmatizar; a esta las divisiones y partidos; y detrás de estos la sangre, los incendios, las sediciones, la anarquía y todos los desastres. ¿Cómo podremos olvidarnos de los estragos que ocasionó en todo el Norte de Europa Lutero?»); compatibilidad del Evangelio con el castigo físico al pecador, en I, 274-280, a partir del ejemplo de la expulsión a latigazos de los mercaderes del templo; veneración de españoles por la Inquisición, en I, 60, y II, 468.

9 Alvarado: Cartas..., I, p. 189, Dios, autor de la sociedad; contra el pacto social, I, pp. 163 («es una patraña ese maldito pacto») y 213-214 («el pacto social [...] no es un hecho, ni tampoco una hipótesis filosófica, sino una imaginación poética»; Rousseau «no parece sino que delira»); la 
No es, en principio, grande el lugar de España en este planteamiento. Los ideólogos anti-revolucionarios se proclaman, desde luego, patriotas y defienden con ahínco las «tradiciones españolas». Tanto así, que llegan a denunciar a los «filósofos» como cosmopolitas y poco patriotas, incapaces de respetar tradiciones y de obedecer a legitimidades constituidas, lo que les convierte en incompatibles con la convivencia humana y peligrosos para cualquier sociedad. Alvarado expresa, en ocasiones, un orgullo derivado de su condición de español que podría tomarse por nacionalismo: «El español nada tiene que envidiar a nación alguna [...] En la guerra nos hemos dejado atrás a las gentes más valerosas. De la navegación hemos sido grandes maestros. En punto a las ciencias hemos competido con los más insignes sabios...» Pero estas declaraciones, cuando se leen en su contexto, redundan en mérito de la Iglesia: «¿A quién debió la España [...] la gloria literaria hasta donde nos elevamos en el gran siglo XVI [...] en el siglo de oro de nuestra España, cuando sabíamos de todo más que toda la Europa junta, cuando éramos el respeto y admiración de las naciones por las armas, por las ciencias, por las artes, por las lenguas y por todas las demás cosas?». La respuesta no deja lugar a dudas: "cuanto la Europa tiene hoy de cultura en todos los ramos, ha sido obra de los monjes y de los frailes» ${ }^{10}$. El fraile español, por tanto, no está cantando las excelencias de los españoles, sino las de los frailes; a ellos les debe todo España. ¿España sólo? Europa; la humanidad entera, en realidad, pues Europa es la cristiandad, faro y centro de la civilización humana.

La singularidad gloriosa de España reside en ser la encarnación del catolicismo: "Yo nací en España, país católico: fueron católicos mis padres, católicos mis maestros, católicos mis sacerdotes, católicos mis príncipes, católicos mis conciudadanos...». No es de extrañar que haya una providencia particular de Dios en favor de tan fiel grupo humano. España fue, ciertamente, la defensora del catolicismo frente a Lutero, y recientemente se ha levantado contra Napoleón decidida a conservar la religión «en toda su pureza»; los españoles «tomaron las armas contra los franceses, principalmente para defender la religión». Cierto también que, según Alvarado, España ha contado con el favor de Dios para vencer al tirano, pero no menos lo es que esa protección sobrenatural está condicionada a que «su conducta general, y la de cada uno de sus hijos, s[ea]n tales que interesen a su favor la divina Providencia». En definitiva, no es una

filosofía como destructora del Estado, en I, 36; incapacidad de la razón humana para rectificar el orden divino, I, 34-35; cfr. I, 32: «Sólo el Evangelio es el que ha descubierto y afianzado los derechos del hombre»; IV, 8-9: «¿De dónde habéis sacado sino del Evangelio esas voces de igualdad, libertad, fraternidad, amor del hombre, beneficencia y demás, cuyo significado ni aun entendéis siquiera?»; desigualdad natural, en I, 161 (cfr. p. 160: «el orden natural exige que unos hombres dependamos de otros»; «Dios nos crió de esta manera»); I, 145-146: desigualdad de cuerpos, desigualdad evidente en los sexos...; necesidad de la nobleza, en I, 152-153; soberanía viene de Dios, en I, 215; imposibilidad de rectificar el orden social, creado por Dios, en I, 34-35.

10 Alvarado: Cartas..., IV, pp. 133 y 193-94. Sobre la falta de patriotismo de los filósofos, v. su referencias a Thomas Paine, en I, 95 y 181.

Hispania, LXI/3, núm. 209 (2001) 831-858 
visión nacional la de Alvarado, sino católica, porque todo el mérito de España depende de su fidelidad a la religión romana y de la conservación de ésta como única del país. Lo cual engarza con la polémica gaditana, momento en que escribe el Filósofo Rancio, que versaba precisamente sobre la supresión de la Inquisición. «¿A quién se le ha debido esta gloriosa resistencia del pueblo español [frente a Napoleón] que pudieron y no supieron oponer otros pueblos? Al Tribunal de la $\mathrm{Fe}$, que lo ha preservado de la seducción que progresó en los otros». El catolicismo - versión inquisitorial - ha hecho que los españoles resistieran a Napoleón. Más aún: buena parte de la resistencia contra los franceses ha sido obra directa de la Iglesia y los frailes, dice Alvarado. La postura de este autor es mucho más católica que española, como prueba el hecho de que no toda la historia de España le parece defendible. Hay en ella puntos oscuros, como los intentos regalistas de diversos reyes, muy en especial de Carlos III, persona devota pero mal aconsejada por el masón Aranda. Tampoco toda la Iglesia española se gana el aplauso del Filósofo Rancio: no lo merecen, por supuesto, aquellos eclesiásticos que apoyaron la expulsión de los jesuitas. Y mucho menos estos liberales que, por mucho que se proclamen católicos, siguen un plan de Federico de Prusia y Voltaire al querer reducir el número de frailes y arrebatar sus bienes a la Iglesia. Estos liberales son españoles "por equivocación», han hecho una Constitución que es mera copia de la francesa revolucionaria y que la nación no siente como propia ${ }^{11}$.

Pese a las repetidas alusiones a la defensa de España y sus tradiciones, no hay, en definitiva, nacionalismo en estos autores. Alvarado, en cierto momento de su diatriba contra la idea de pacto social, deja caer: «ipor dónde se nos ha aparecido [.... esta nación a quien ahora se le cuelga la soberanía?» ${ }^{12}$. La idea de nación supone, en efecto, considerar depositarios de la soberanía a los hombres, y no a Dios, único ente que merece el nombre de «soberano», y por tanto es una más de las perversas invenciones de la modernidad. El nacionalismo, en definitiva, es equivalente al ateísmo; confiere atributos divinos al Estado, coloca la razón humana - encarnada en algo tan inestable y banal como la opinión pública - en el lugar de la razón divina. Muchas décadas más tarde, al iniciarse el último cuarto del siglo XIX, El Siglo Futuro, órgano del carlismo integrista, heredero de estos contrarrevolucionarios de la era fernandina, seguirá explicando que la teoría liberal del Estado equivale al ateísmo, pues hace del poder pú-

11 Alvarado: Cartas..., I, pp. 281 y 323; II, 469; III, 127; IV, 125 y 244-246; cfr. II, pp. 341 («نPiensan que el pueblo español dejará de oír a sus obispos...? [...] cel carácter español es susceptible de tantas, tan pueriles y tan absurdas ligerezas...?») y 463 («¿Y aunque Dios nos diga que seamos católicos, ¿podrá el Congreso determinar que no lo seamos? infeliz España!»); providencia particular, en II, 340; defensa de la religión frente a Napoleón, en I, 28 y 74; los legisladores católicos no pueden admitir la diversidad de religiones, en II, 462; en II, 383, eclesiásticos que apoyaron expulsión de los jesuitas; plan de Federico de Prusia, en III, 418-421; legitimidad de la posesión de sus bienes por la Iglesia, en IV, 124; españoles «por equivocación» en III, 104.

12 Alvarado: Cartas..., I, p. 212. 
blico la representación de un «yo colectivo» que sólo se atiene a una razón autónoma e independiente y sirve a los derechos y deseos del conjunto de los ciudadanos: «no reconoce sobre sí ningún otro poder [...] porque el Estado es la humanidad misma bajo una forma social»; de esta manera, «o niega a Dios o diviniza al hombre, que es lo mismo» ${ }^{13}$. Para esta extrema derecha clerical española del XIX, la soberanía no radica en el Estado, representante de la nación, ni en voluntad humana alguna. Pretender tal cosa forma parte de las rebeliones modernas: según explicó en su día Hervás, éstas comenzaron por la predicación de la «libertad de los reyes contra la Iglesia», para seguir por la de los pueblos contra los reyes y llegar ahora a la igualdad absoluta, la negación de cualquier preeminencia social. Al tambalearse la religión —como estos pensadores creían que estaba ocurriendo-, desaparecían los fundamentos morales para la sumisión. No podían comprender que el mundo moderno iba a erigir a la nación en nueva base de la legitimidad política, de la identificación emocional de los ciudadanos con el Estado, y que de esta forma la autoridad alcanzaría tanta o mayor solidez que en la etapa anterior, cuando estaba sancionada por la religión.

Aparte de su maniqueísmo, y de su conservadurismo impermeable a cualquier concesión, llama la atención en esta visión de la realidad política del XIX su angustioso sentido apocalíptico, su "mentalidad de resistencia», según los términos que Julio de la Cueva aplica al catolicismo español de época algo posterior, cuando la Iglesia se veía a sí misma «como una fortaleza sitiada en medio de un mundo hostil» ${ }^{14}$. Ese mundo hostil es la modernidad, nuevo Anticristo que aparecía, además, con todas las trazas de triunfador. De ahí que el mensaje político fundamental de este discurso sea un llamamiento a los católicos, no ya para triunfar, sino para defenderse y resistir frente a este asalto generalizado de un mundo moderno que tenía todo el aspecto de estar sólo iniciando su andadura.

Por eso, la culminación de esta línea teórica en España sería el último Donoso Cortés, el gran reaccionario de mediados de siglo, con el que interesa terminar este apartado para reafirmar cuán ajeno era este planteamiento al sentimiento nacional. Juan Donoso Cortés, marqués de Valdegamas, embajador español en París durante los acontecimientos revolucionarios de 1848, es uno de los escasos pensadores políticos peninsulares que ha tenido cierta repercusión en Europa. Mas ello puede que se deba, precisamente, a que planteó su obra al margen de los problemas españoles. La lucha que él creía percibir no era de España contra la anti-España, sino del catolicismo contra los demonios de la modernidad: el materialismo, la inmoralidad, la revolución destructora de la civilización. Y en el sentido apocalíptico con que vivió esta lucha nadie le superó. Creyéndose un nuevo Agustín de Hipona en presencia del derrumbamiento del imperio romano, concibió su Ensayo sobre el catolicismo, el liberalismo y

13 "Cuestiones teóricas sobre el liberalismo", 21 y 24-XII-1875.

14 «Cultura y movilización en el movimiento católico de la Restauración (1899-1913)», en SuÁrez CoRTiNA, Manuel, ed.: La cultura española de la Restauración, Santander, 1999, pp. 178-179.

Hispania, LXI/3, núm. 209 (2001) 831-858 
el socialismo cual nueva Ciudad de Dios, girando en torno a la grandiosa batalla final entre la civilización católica y el error racionalista ${ }^{15}$. Porque el origen del problema se situaba, para él, al igual que para Hervás y Panduro, Ceballos, Barruel, De Maistre o Alvarado, en el racionalismo. «La razón sigue al error adonde quiera que va», dijo, en uno de esos aforismos para los que tan bien dotado estaba; y en otra ocasión: «entre la verdad y la razón humana, después de la prevaricación del hombre, ha puesto Dios una repugnancia inmortal y una repulsión invencible». Otra de sus fórmulas, tan contundentes como arbitrarias, describía las sucesivas encarnaciones del «error racionalista»: en el siglo XVII en el protestantismo, en el XVIII en el filosofismo ilustrado, en el XIX en el liberalismo y, por fin, en 1848 había revelado su verdadera faz, que era el socialismo; un socialismo anarquizante, como el de Proudhon, en quien Donoso localizaba al nuevo Anticristo, el dirigente de las hordas revolucionarias que venían a destruir toda preeminencia y toda civilización; marea destructora que desembocaría, sin embargo, en lo contrario a la anarquía, en una tiranía populista de dimensiones nunca soñadas. Frente a ello a Donoso Cortés sólo se le ocurre clamar por una «reacción religiosa», por una «dictadura católica», una Autoridad divina e implacable; la pedía para España, pero también la creía necesaria para Europa, pues el problema excedía con mucho de lo nacional ${ }^{16}$.

Salvo en la contundencia de sus fórmulas - y en la calidad de su prosa-, no hay ninguna novedad, como puede verse, en el Donoso Cortés de 1848 respecto de los Alvarado o Barruel de treinta o cincuenta años antes. «Detrás de toda cuestión política hay siempre una cuestión religiosa», rezaba otro de los axiomas que le hicieron célebre, y era lo que todos ellos habían querido decir: que el racionalismo moderno era una teología satánica, y de ahí su inevitable evolución desde el protestantismo hasta el filosofismo ilustrado, el liberalismo revolucionario y, finalmente, el igualitarismo socialista y la barbarie anárquica. Donoso creía, en efecto, como cualquiera de los contrarrevolucionarios que han sido objeto de este capítulo, en la incompatibilidad más absoluta entre la civilización católica, basada en la sumisión a las jerarquías naturales y la represión de los instintos perversos, y cualquier organización sociopolítica que confiara en

15 O. C., ed. de JuretschKe, Hans, Madrid, 1946, vol. II, pp. 368, 409 y 437. Es obvio que no nos referimos en estos párrafos sino al Donoso Cortés de la última etapa; para su etapa juvenil, doctrinaria, v., p. ej., ÁlvAREZ JunCO, José: «Estudio preliminar» a DONOSO CORTÉs, Juan: Lecciones de Derecho político (1835), Madrid, Centro de Estudios Constitucionales, 1984, pp. VII-XXXVII. En general, sobre todo esto, v. LÓPEZ ALONSO, Carmen: «El pensamiento conservador español en el siglo XIX», en VAlleSPín, Fernando: Historia de la teoría política, Madrid, 1993, V, 273-314.

16 Así lo reconoce incluso GuTIÉRrez LASANTA, F., autor de una de tantas obras absurdas sobre este pensador, Donoso Cortés, el Profeta de la Hispanidad, Logroño, 1953; pese al título, que en absoluto se justifica en las páginas de la obra, y pese a un capítulo titulado "Profeta y tratadista de España», cuyo interior tampoco se corresponde con el enunciado, en p. 75 el autor se ve obligado a reconocer que «Donoso Cortés fue ante todo y sobre todo europeo». Sobre el irracionalismo (más que romanticismo) de Donoso, v. LLORÉNS, Vicente: El romanticismo español, Madrid, 1979, pp. 557-559.

Hispania, LXI/3, núm. 209 (2001) 831-858 
la razón natural y buscara la satisfacción de los impulsos y necesidades terrenales de la humanidad. «Seréis como los ricos», era la fórmula de las revoluciones proletarias, como «seréis como los nobles» había sido la de las revoluciones de las clases medias, pero ambas se remontaban al «seréis como los dioses», primera expresión de la soberbia y la rebelión humana en el paraíso. Como concluye Begoña Urigüen, «el principio más radical del anti-moderantismo donosiano [es] la irreconciliabilidad entre la verdad y el error, entre la Religión y la Filosofía, entre la Iglesia y la Revolución» ${ }^{17}$.

Lo que interesa en este libro es que en el planteamiento de este gran representante del conservadurismo español de mediados del XIX sigue sin caber la nación. La nación era tan sospechosa para él como lo había sido para los teóricos del absolutismo fernandino, una sospecha que se reforzó sin duda ante los fervores nacionalistas que le tocó presenciar durante las revoluciones de 1848 . «Un pueblo que proclama su soberanía - escribe - es un pueblo que proclama su unidad y un pueblo que proclama su unidad es un pueblo que reclama su existencia»; los que «adoran la soberanía popular adoran un absurdo [...] ¿cuál es el error funesto que ha podido conducir a los hombres que combato a tal absurdo sin que se espanten de sus terribles consecuencias? Vedle aquí: ellos han creído que, en el estado normal de las sociedades, el pueblo es un ser, cuando sólo es un agregado de seres; es decir, un nombre. De aquí resulta que los que adoran su soberanía, a un nombre sólo adoran; que los gobiernos que [...] se declaran sus servidores, a un nombre sólo sirven. [...] En el estado normal de las sociedades, no existe el pueblo, sólo existen intereses, [...] opiniones, [...] partidos» ${ }^{18}$. Es comprensible que se enfrentara explícitamente con González Bravo, político de origen liberal que también evolucionaba en aquel momento también hacia un conservadurismo extremado, pero que lo basaba en una radical afirmación de los derechos de la nación española. Donoso, por el contrario, piensa desde un punto de vista europeo. Su inspiración viene de Augustin Barruel, de Joseph de Maistre y de todo el pensamiento anti-ilustrado franco-italiano (Bergier, Nonotte, Valsechi, Mozzi...) en el que bebieron también los Vélez y Alvarado. Mucho más cosmopolita que éstos, Donoso se siente abiertamente europeo y se dirige a un público europeo, y publica su Ensayo sobre el catolicismo en francés, a la vez que en español. Escribió también en aquéllos años, últimos de su vida, un Llamamiento a los conservadores (europeos) e hizo

17 Donoso Cortés, Juan: Obras Completas, ed. de VAlverde, Carlos, Madrid, 1970, vol. II, p. 312; socialismo como teología satánica, en II, pp. 597-600 («el socialismo no es fuerte sino porque es una teología y no es destructor sino porque es una teología satánica»; de ahí que prevalezca sobre la escuela liberal, que es «antiteológica y escéptica»). URIGÜEN, Begoña: Orígenes y evolución de la derecha española: el neo-catolicismo, Madrid, 1986, p. 60.

18 O. C., ed. de H. JURETSCHKE, vol. I, pp. 197-198. Más contra la soberanía popular, equivalente a ateismo, en 0 . C., ed. de C. Valverde, vol. I, p. 348 («la soberanía de derecho es una e indivisible: si la tiene el hombre, no la tiene Dios; si se la localiza en la sociedad, no existe en el cielo. La soberanía popular es, pues, el ateísmo»). 
lo que pudo - incluidas gestiones cerca de Luis Napoleón y del retirado Metternich - por llegar a una alianza antirrevolucionaria de las monarquías cristianas continentales que contrarrestara la política liberal de los ingleses. Una alianza que debería estar apadrinada y protegida por la Iglesia, única verdaderamente capaz de salvar a las sociedades del "peligro de muerte» que las amenazaba ${ }^{19}$. A través de Louis Veuillot, los ecos del pensamiento donosiano se dejarían sentir con nitidez sobre Pio IX y el Syllabus. Vale la pena añadir un par de datos últimos sobre esta línea de pensamiento para probar su orientación abiertamente anti-nacional.

De Barruel, es curioso saber que fue en sus Memorias para servir a la bistoria del jacobinismo, de 1798, donde apareció por primera vez la voz nacionalismo. Y en el mismo párrafo en que inventa ese término que iba a repetirse hasta la saciedad en los dos siglos siguientes, queda claro también el carácter negativo que atribuye al fenómeno, para él una de tantas invenciones perversas de la modernidad. Según explica Eugene Kamenka, nacionalismo significaba, para el abate Barruel, "derrocar gobiernos legítimos cuyo derecho a ejercer la autoridad se basaba en la voluntad divina o en derechos hereditarios», lo cual estaba ligado con «el terrible espíritu de la masonería y la ilustración, anclado en el egoísmo». Dejemos la palabra al propio abate: «Le nationalisme, ou l'amour national, prit la place de l'amour général à l'humanité [...] Alors, ce fut une vertu de s'étendre aux dépens de ceux qui ne se trouvaient pas sous votre empire. Alors, il fut permis, pour atteindre ce but, de mépriser les étrangers, de les tromper, de les offenser. Cette vertu fut appelée Patriotisme [...] enfin l'Egoisme». El abate contrarrevolucionario no dejaba de tener razón, al considerar el nacionalismo una expresión de egoismo colectivo. Pero habrá que reconocer que no ése era el clima adecuado para el surgimiento de un nacionalismo español interpretado en términos católico-conservadores.

El mundo conservador no tenía más que recelos ante el nacionalismo. Es célebre la conversación entre Metternich y Louis Veuillot en que el primero le hizo observar al segundo que «cuando la lengua francesa añade el isme a un sustantivo, añade algo degradante a esta idea», enunciado que se le ocurrió ilustrar inmediatamente con tres casos: «théisme», «libéralisme» y «nationalisme» ${ }^{20}$. Para el canciller austríaco, el nacionalismo era uno de los primeros ejemplos que le venían a la mente de lo extremado y peligroso de la política moderna. Era el momento en que el Vaticano no apoyaba ni siquiera el católico

19 O.C., ed. de C. Valverde, vol. II, pp. 653, 894-895 y 910; Graham, John T.: Donoso Cortés, Utopian Romanticist and Political Realist, University of Missouri Press, 1974, cap. 9. Sobre el pensamiento franco-italiano que les inspira, v. ABELLÁN, José L.: Historia crítica del pensamiento..., IV, p. 179.

20 Barruel, cit. por KAMENKA, Eugen: Nationalism. The Nature and Evolution of an Idea, Australian University Press, 1973, p. 8; tomado, a su vez, de De Bertier fe SAuvignY, G.: «Liberalism, Nationalism and Socialism: the Birth of Three Words», The Review of Politics, 1970, 32 (2), pp. 155; en este artículo, p. 150, la anécdota de Metternich.

Hispania, LXI/3, núm. 209 (2001) 831-858 
nacionalismo polaco. A sugerencia de Lamennais, surgieron dudas sobre la conveniencia de seguir esta linea, y hubo un período de coqueteos guelfistas, pensando en hacer del papado el eje de la unidad italiana. Pero el vendaval revolucionario del 48 arrasó con esta breve tentación. Y, a partir de entonces, el otrora liberal Pio IX se enfrentó con la idea de nación, como se enfrentó con el liberalismo. Y en 1864, tras ver cómo le arrebataban sus territorios pontificios los nacionalistas italianos, publicó su célebre Syllabus, en el que, siguiendo fielmente lo teorizado por Barruel, Joseph de Maistre, Alvarado o Donoso, anatematizaba a diestro y siniestro. Todo era condenable: el racionalismo, el deismo, la tolerancia, el liberalismo, el socialismo... y el nacionalismo, bajo la forma de la fundamentación estrictamente laica o natural del poder político. El enunciado número ochenta resumía, en cierto modo, las setenta y nueve condenas anteriores y la posición papal in toto, declarando imposible cualquier reconciliación de la Silla de Pedro con «el progreso, el liberalismo y la civilización moderna». Con el paso del tiempo, y tras no pocas dudas y dificultades, sus sucesores han rectificado esa línea. Por suerte, porque de haber continuado por ella la Iglesia católica podía haber terminado en una secta marginal y extravagante, con un número de seguidores más reducido cada año.

Es significativo que la aparición del Syllabus únicamente fuera saludada con aplauso por los integristas de Ramón Nocedal, en España - y en otros países por sus equivalentes-, tan extremadamente conservadores que acabarían siendo inaceptables incluso para los carlistas. Ramón Nocedal, el dirigente de aquella fracción, se consideraba heredero intelectual de Donoso Cortés; y, en esto al menos, tenía razón. Como la tenía Pidal y Mon, el dirigente del catolicismo moderado, que hacia 1880 llevó a buena parte de los antiguos tradicionalistas a las filas del conservadurismo canovista, cuando calificó la influencia de Donoso Cortés sobre el catolicismo español de una «calamidad» ${ }^{21}$.

$Y$ es que el conservadurismo español de la segunda mitad del siglo estaba rectificando su línea de las décadas anteriores. Iba a seguir identificándose con el catolicismo, y defendiendo la «patria» y las sacrosantas «tradiciones españolas», pero también empezaría a combinar aquél con éstas en una amalgama que mucho después se llamaría nacional-catolicismo. Al aceptar y desarrollar la idea de nación, se integraba así en el mundo moderno. Esperemos que, a estas alturas de nuestra indagación, nadie tome esto como un juicio de valor: la modernidad no es necesariamente positiva ni negativa; de todo tiene; pero quien no se integra en ella, no sobrevive. Para bien o para mal, en fin, el conservadurismo católico español se adaptó a los mínimos exigidos para sobrevivir en el mundo moderno.

Para esa identificación de la entidad nacional llamada «España» con el catolicismo se hacía precisa una reelaboración de la historia. Y ésta fue la tarea fundamental de una serie de autores, emprendida justamente en los últimos

${ }_{21}$ URIGÜEN, B.: Orígenes y evolución de la derecha..., cit., p. 55. 
años del reinado isabelino, es decir, con un apreciable retraso respecto de las historias nacionales de inspiración liberal. Entre sus títulos más destacados podrían mencionarse el Compendio de Historia de España, de Antonio Cavanilles; las Reflexiones sobre la España, del presbítero Francisco Belmar; la Historia de la Literatura Española de Amador de los Ríos; el Crisol Histórico Español de Ferrer de Couto; las tres Historias de España publicadas en 1867 por Monreal y Ascaso, Sánchez y Casado y Orodea e Ibarra; la Historia eclesiástica de España de Vicente de la Fuente y, como coronación de esta serie, la Historia de España, de Manuel Merry, en $1876^{22}$. En algunos casos se trataba de auténticas historias de la Iglesia española, recicladas y disfrazadas como historias nacionales; en otros, como en el de Vicente de la Fuente, bajo el nombre de historia eclesiástica se ocultaba una historia que muy bien podría llamarse nacional. En conjunto, todas ellas esbozaron el mito historiográfico nacional-católico, que llevaría a su culminación Menéndez Pelayo. Hagamos un breve alto para analizar esa idea que tenían del pasado, subrayando sus diferencias con la versión nacionalista que habían elaborado los liberales.

El sujeto inicial del relato no es la nación. No comienza todo con la constatación de que desde los más remotos tiempos existió «España» y hubo en ella pobladores que merecían el nombre de «españoles». Como habían hecho los absolutistas fernandinos, el marco inicial son las coordenadas bíblicas y el sujeto son aquellos personajes que antecedieron al pueblo de Dios. Alguno de los autores citados, como Merry, declara su adhesión a la versión bíblica de la creación, con explícita repulsa de la «doctrina absurda del inglés Darwin»23. Dentro de ese relato bíblico se encuentra, aunque no era fácil, un lugar para «España»: por un lado, al seguir manteniendo, en tiempos que ya empezaban a ser ridículas, las referencias a Túbal, «hijo de Jafet, uno de los dos benditos por Noé», que se suponía había sido el primer poblador de la Península; gracias a Túbal, «este país, desierto entonces, nació a la vida de los pueblos, teniendo religión, gobierno monárquico y leyes», importantes rasgos iniciales que debían

22 Cavanilles, Antonio: Compendio de Historia de España, Madrid, 1860, 5 vols.; Belmar, Francisco S.: Reflexiones sobre la España, desde la fundación de la monarquía basta el fin del reinado de San Fernando, Madrid, 1861; AMADOR DE LOS RIOS, José: Historia crítica de la literatura española, Madrid, 1861; FERRER DE COUTO, José: Crisol bistórico español y restauración de las glorias nacionales, La Habana, 1862; MONREAL Y ASCASO, Beranardo: Curso de Historia de España, Madrid, 1867; SÁNCHEZ Y CASADO, Félix: Prontuario de Historia de España y de la Civilización Española, Madrid, 1867 (citado por ed. Hernando, 1900); Orodea E IBARRA, Eduardo: Curso de Lecciones de Historia de España, Valladolid, 1867; DE LA FUENTE, Vicente: Historia eclesiástica de España, Madrid, 1873-75, 5 vols. (2a ed. corr. y aum.); MERRY y Colón, Manuel: Historia de España, Sevilla, 1876, 2 t. en 1 vol. La obra fundamental que debe seguirse en torno a este tema es BOYD, Carolyn: Historia Patria, Princeton, 1997 , en especial cap. 4.

23 MERRY y COLÓn, M.: Historia de España..., cit. p. 23. Suyos son también unos Elementos de bistoria crítica de España, Sevilla, 1892, 3 t. en 1 vol.; y en 1889 escribió una tercera obra, esta vez, con Merry y Villalba, Antonio, titulada Compendio de Historia de España, Sevilla, dedicada «Al Episcopado Español». 
acompañar a la nación a lo largo de su historia. Otros autores, como Francisco Belmar, establecen una conexión incluso más estrecha, al describir cómo, «cuando las aguas del diluvio se retiraban, aparecía, por orden de Dios, entre los Pirineos y el Estrecho de Gibraltar, [...] el bello país conocido con el simpático nombre de España...»; casi en la misma página, hace surgir, triunfante de las catacumbas, a la Iglesia; y conecta ambos eventos al observar que «el pueblo y el reino que rehusasen servirla [a la Iglesia] debían perecer devastados por la soledad», mientras que «la grandeza y la prosperidad, a la sazón reservadas a la España del porvenir, debían seguir las mismas peripecias de su obediencia y homenajes hacia la Iglesia católica» ${ }^{24}$. Según cualquier esquema mítico, los triunfos y fracasos de la identidad colectiva se explican por su fidelidad o traición a su origen; de ahí la importancia de los orígenes. En el caso de la nación española, para estos autores, importa mucho dejar establecido su origen como religioso.

Otra forma de vincular, desde el surgimiento mismo de la nación, religión e identidad colectiva, consiste en subrayar la innata religiosidad de aquellos primeros habitantes de la Península, a los que se llama «españoles». No sólo eran religiosos, sino que su religión fue, desde mucho antes de que llegaran las prédicas cristianas, instintivamente monoteista, contraria a la idolatría. Pese a tratarse de un asunto sobre el que, por supuesto, aquellos autores carecían del mínimo de datos necesarios para emitir un juicio -frecuentemente, se protegen con un "parece que» o "tal vez", al iniciar sus frases-, leemos cosas tan atrevidas como que «estos pueblos cayeron mucho menos, o nada, en la idolatría; antes parece que conservaron puras la revelación primitiva y la luz natural»; «la religión natural importada por Túbal» consistía en «un solo Dios, creador del Universo, incorpóreo e incorruptible» y se conservó hasta que «la idolatría fenicia» la corrompió; «todos los autores pintan las costumbres de aquellos primeros pueblos como puras y sencillas, hasta que se depravaron con el comercio y dominación extranjera [y] hubieron de malearse desgraciadamente con el trato de aquellos idólatras»; «conquistados los españoles por los romanos, recibieron luego con su civilización todos los errores de su politeísmo [...] Los actos de adulación e idolatría que entonces se dieron, deben recaer sobre sus conquistadores» ${ }^{25}$. La diferencia con la versión nacionalista de la primera mitad del XIX consiste aquí en anteponer la religiosidad monoteísta a la belicosidad de los primitivos españoles, aunque esta última tampoco se niegue.

El apogeo de la religiosidad llegaba, de todos modos, con la predicación del cristianismo, cuyo éxito todos insistían en presentar como fulminante. Ya el padre Flórez, en el siglo XVIII, había mantenido que España había sido el primer país cristianizado. Por entonces, aquello no pasaba de ser una mera disputa eclesiástica, una competición por la primacía entre las distintas ramas de

24 BeLMAR, F. S.: Reflexiones sobre la España..., cit., pp. 9-11.

25 Monreal y Ascaso, B.: Curso de Historia de España..., p. 20; Merry y Colón: Historia de España..., p. 59; y DE LA FUENTE: Historia eclesiástica de España..., pp. 28 y 35.

Hispania, LXI/3, núm. 209 (2001) 831-858 
la Iglesia universal. Ahora, ya, en plena era de los nacionalismos, lo que se debatía era la identidad religiosa de la nación. Para Sánchez y Casado, la propagación del cristianismo «fue muy rápida y muy próxima a la muerte del Salvador»; «España la recibió con entusiasmo - añade Orodea-, porque el cristianismo era la religión de los pueblos libres»; y Merry ratifica: se recogieron «frutos copiosísimos de la predicación evangélica», con lo que España fue «una de las primeras naciones del mundo en escuchar y seguir la santa doctrina de Nuestro Señor Jesucristo». Belmar explica el significado de este hecho: los "primitivos españoles» habían mostrado ya su valor frente a cartagineses, romanos y otros invasores, "pero esos latidos del noble corazón de España [...] eran insuficientes para asimilar y refundir en una sola las diferentes razas de sus habitantes. [...] Sólo a Cristo crucificado [...] estaba reservado hacer de distintos pueblos un sólo pueblo»; apareció, al fin, el apóstol Santiago y «he aquí el fundamento de una de las más gloriosas nacionalidades de Europa» ${ }^{26}$. La idea era fácil de sintetizar: la religión católica creó la nación española.

El apóstol Santiago era, por tanto, más que Túbal, el fundador de la nacionalidad. Y los historiadores nacional-católicos no consienten dudas, aunque tampoco aporten datos nuevos, sobre la llegada del apóstol a la Península. Castellanos de Losada asegura que España fue «uno de los primeros pueblos que tuvieron la dicha de ver la clarístima luz del Evangelio, y esto aun viviendo María Santísima, que se dignó visitar nuestra patria y señalar al apóstol Snatigao [...] el sitio en que había de levantarla un templo». Como dice De la Fuente, «la nación española ha considerado siempre este hecho como una tradición constante e inconcusa»; ha sido una creencia "general, continua y unánime», como lo es «la venida de la Virgen a visitarle a Zaragoza». Merry llama «imprudentes» a quienes dudan de estas "glorias» y en la obra conjunta con su pariente precisa, aunque no juzgue imprescindible citar la fuente de su información, que Santiago «moró nueve años en la Península» ${ }^{27}$.

El relato de la resistencia a la conquista romana es sustancialmente idéntico al del canon historiográfico nacionalista, aunque se tienda a pasar más rápidamente por las hazañas bélicas y se subraye lo positivo de la cristianización bajo

26 SÁNChez y CASAdo: Prontuario de Historia de España..., p. 32 (añade que el cristianismo fue predicado "por los propios apóstoles», y que el Pilar es «nuestro monumento más sagrado»); ORODEA E IBARRA: Curso de Lecciones de Historia..., p. 54; MERry y Colón: Historia de España..., p. 114, y Elementos de historia crítica..., p. 83; BELMAR: Reflexiones sobre la España..., p. 13. Cfr. MONREAL Y ASCASO: Curso de Historia de España..., p. 38 (propagación del cristianismo, muy rápida en España).

27 CASTEllanOS DE LOSADA, Sebastián: Memorandum Historial, 1858, p. 191; DE LA FUENTE: Historia eclesiástica de España..., Vol. I, p. 46; MERRY Y COLÓN: Historia de España..., p. 114; MERRY Y COLÓn y MERRY y VILlalba, Compendio de Historia de España..., p. 18, todos coinciden en que también visitó España San Pablo; y en que a Santiago se le apareció la Virgen en Zaragoza. Las historias eclesiásticas tradicionales daban por supuesta la predicación por Santiago (v., p. ej., España sagrada de FlóREZ, Enrique, 1754, vol. III, pp. 39-131; XIX, 164). Cfr. El Amigo de la Religión, 1837, p. 353 («particular predilección de la Santísima Madre del fundador del cristianismo» por este país). 
Roma. Especialmente interesante es la llegada de los visigodos, y sobre todo sus casi dos siglos de dominación inicial, cuando los dominadores eran cristianos, pero arrianos, e impusieron esta herética doctrina en el país católico por excelencia. Su interés se deriva de que se revela entonces el límite fundamental de estas adaptaciones de las historias eclesiásticas a la versión nacional. La «España» de los godos, en la medida en que su orientación política no coincidía con la de la Iglesia católica, no era necesariamente el héroe del relato mítico. Hay que recordar que la conversión de los francos al catolicismo ocurrió en tiempos de Clodoveo, un siglo antes que Recaredo, y que los católicos francos y los godos arrianos mantuvieron, a lo largo de aquel siglo, varias guerras. iA favor de quiénes podía situarse un historiador que se consideraba, a la vez, nacionalista español y devoto católico? No era flojo el dilema. Había antecedentes de quienes se habían decantado hacia el lado religioso, más que hacia el nacional, como Manuel Ortiz y Sanz a finales del siglo XVIII: "Mientras Alarico desfogaba su encono contra los católicos, tuvo la Iglesia Galicana el consuelo de ver Católico a su gran Rey Clodoveo. Era el único Monarca del mundo que a la sazón profesaba la Religión verdadera...». Surgieron problemas con Alarico y «sintiólo mucho el Franco», pero se vio obligado a hacer la guerra. «Derrotados los Godos y Alarico muerto por mano del mismo Clodoveo", eligieron los godos por nuevo rey a Amalarico, «pero nuestro Rey Amalarico por desgracia conservaba un furioso rencor contra los Católicos»; casado con Clotilde, hija de Clodoveo, prometió respetar su catolicismo, pero su «herética pravedad y celo» no se lo permitió y comenzó a tratarla con «asperezas y crueldades»; "pocas veces los sectarios dejan de ser crueles», reflexionaba en medio del relato Ortiz y Sanz, «la verdadera mansedumbre y piedad es cosa muy rara fuera de la Religión Católica». Soportó Clotilde pacientemente mil injurias, pero cuando Amalarico llegó a "poner sus brutales manos en la virtuosa princesa», no pudiendo "vencer o mitigar tanta fiereza», ésta escribió a sus hermanos y les envió «un lienzo lleno de sangre que había cogido en uno de sus diarios atropellamientos». Estalló nueva guerra y el hereje visigodo fue, de nuevo, derrotado por los católicos francos; Amalarico huyó, y hasta intentó refugiarse en una iglesia católica; «a sus umbrales fue muerto de una lanzada, no queriendo Dios fuesen su asilo templos que tanto había profanado». Ésta es la versión que mantendrá todavía Menéndez Pelayo casi cien años después ${ }^{28}$.

Interesante caso de en que se inserta toda una fase «errónea» de la vida del ente nacional, por ser infiel a la religión. Problema no muy diferente al que

28 ORTIZ y SANZ, José: Compendio cronológico de la Historia de España, Madrid, 1795, 6 vols., vol. II, pp. 96-101. Cfr. p. 105: invasión de Justiniano en la parte meridional de España, «con general alegría de los naturales al verse regidos de Príncipe Católico». Justiniano logró expulsar a los godos, francos y alemanes, y si no terminó con todos los bárbaros y recuperó el Imperio antiguo entero «seguramente fue inminente el peligro y sólo la flojedad, vejez y sospechosa religión de Justiniano pudieron ser causa». Sin embargo, M. Merry y Colón (Historia de España..., p. 24) culpa a la «ambición de Clodoveo» de las guerras con Alarico. M. Menéndez Pelayo, Historia de los beterodoxos..., I, III, VI.

Hispania, LXI/3, núm. 209 (2001) 831-858 
planteaba San Hermenegildo, príncipe que, en definitiva, se había rebelado contra su padre, el rey Leovigildo, lo cual constituía una grave falta contra la autoridad familiar, aparte de un crimen de Estado. Ya en tiempos de San Leandro y San Isidoro, los propios cronistas católicos tuvieron dificultades para justificar la acción de Hermenegildo. Para un nacionalista del siglo XIX, parece que el reforzamiento del Estado requeriría incluso mayor dureza con aquel rebelde. Pero no es así, porque la fidelidad a la Iglesia puede más que la del Estado. En algún caso, como hace Cavanilles, se niega que hubiera rebelión: Hermenegildo se limitó a convertirse al catolicismo y Leovigildo trató de «violentar la conciencia de su hijo", aparte de perseguir a los súbditos "cristianos»" 29 del sur de España, lo que obligó a Hermenegildo a «defender su reino y proteger a sus vasallos»; le atacó, entonces, Leovigildo y, habiéndole hecho su prisionero, le quiso obligar a comulgar de manos de un obispo arriano; «negóse con valor y ofendido el padre mandó cortar la cabeza a su propio hijo». En otros casos, como el de Monreal, hubo rebelión, pero espontánea, no dirigida por el príncipe: Hermenegildo se convirtió, y cambió su nombre a Juan, y ello fue «como la señal de la sublevación [...] pues siendo en su inmensa mayoría los españoles católicos», era «natural» que volvieran su vista al príncipe convertido. Otros autores, por último, son más militantes: Merry, por ejemplo, reconoce que Hermenegildo se declaró en guerra contra su padre, pero considera tal guerra «justa», según los requisitos que Santo Tomás exige para declarar así un conflicto, pues «su causa era justa, su fin honesto y él tenía autoridad legítima como rey de su pueblo» 30 .

Las campanas repican a gloria cuando entra en escena Recaredo. Ahí se fundó, verdaderamente, la nacionalidad. Todos los autores mencionan el hecho y lo ensalzan con sus parabienes. Retengamos solamente los tres más significativos. Belmar llama a Recaredo «el apóstol de su pueblo y el fundador de la monarquía católica en España», que «libertó» al país de la herejía arriana que durante dos siglos lo «había agobiado con sus perniciosos efectos» y construyó un orden firme y perfecto, donde los «derechos naturales» se veían asegurados y limitados doblemente por la fe y la política. La monarquía española, así, «fundada sobre la verdadera fe, fue desde su principio un edificio de la más

29 Curioso lapsus, muy repetido, éste de llamar «cristianos» a los católicos, dando a entender que quienes no aceptan las definiciones dogmáticas de la Iglesia no son cristianos.

30 Cavanilles, A.: Compendio de Historia de España..., vol. I, pp. 210-211; MONREAL y AsCASO: Curso de Historia de España..., p. 61; MERRY y MERRY: Compendio de Historia de España..., p. 31. Cfr. SÁnCHeZ y CASAdo: Prontuario de Historia de España..., pp. 50-51; o DE LA FuENTE: Historia eclesiástica de España..., vol. I, p. 199 ( «la guerra civil religiosa promovida por San Hermenegildo...»). MERRY y COLÓN: Historia de España..., p. 36, es más duro con el príncipe rebelde: «Lleno del fervor del recién convertido», fue «instrumento de la pasión política»; su santidad no se basa en que «se sublevara una y otra vez contra su padre y rey», sino en «la fortaleza heroica con que se resistió a renegar de la fe». BELMAR: Reflexiones sobre la España..., pp. 15-16, se limita a hablar del «ilustre mártir», de la sangre derramada por un padre «desnaturalizado» que no pudo hacer de él un apóstata. 
sólida firmeza». Belmar aprovecha el momento para teorizar y explica que los ciudadanos católicos son los más sociables y su sociedad la más feliz, mientras que Estados sin religión sólo tienen «aparente felicidad», están «flotantes sobre el aire» y se desvanecen a la primera tempestad. Vicente de la Fuente, segundo autor que mencionaremos, explica que «el arrianismo era el protestantismo de los primeros siglos», «la religión de los conquistadores, de los bárbaros», «la valla que separaba las castas y continuaba perpetuando los odios entre vencedores y vencidos», mientras que el catolicismo era «la religión de los españoles, de la civilización y la antigua cultura romana», y simbolizaba «la libertad para los españoles oprimidos, la ilustración, la civilización, la fusión de las razas y la unidad nacional». Los Merry, por último, dicen que con Recaredo «la nación española» se convirtió en la más adelantada en la Europa del siglo VII, y aclara: «todo ello fue debido única y exclusivamente al clero, al episcopado español» ${ }^{31}$.

Vimos ya, al tratar de la historiografía nacionalista liberal, el problema con que se enfrentan estas visiones míticas cuando tienen que explicar el final, la desaparición de aquellas situaciones históricas que han ensalzado previamente como perfectas o paradisíacas. El caso del reino visigodo, que según parece había logrado crear una nacionalidad española tan sólida, era verdaderamente notable por la facilidad con que se derrumbó, tras una sola batalla. A decir verdad, los minúsculos pretextos a que recurren estos historiadores no se diferencian mucho de las explicaciones ofrecidas por los liberales: los «vicios» personales de un par de reyes sirven para probar la «degeneración» de todo un pueblo. Según Belmar, de Witiza se apoderaron las pasiones más feroces y los vicios más groseros; de don Rodrigo también se habla de la «licencia de su vida» y la «opresión sobre sus súbditos»; con lo que puso «el cuello de su noble patria bajo la estúpida planta del salvaje africano»; sin embargo, también hay en Belmar un detalle revelador: «así desapareció la nacionalidad española en el momento en que fue atacada la Iglesia en su divina libertad», que da a entender que hubo alguna discrepancia entre la linea política de los reyes y la jerarquía eclesiástica. Manuel Merry, por su parte, describe igualmente cómo el imperio romano se había visto «sumergido en el más horrendo caos de corrupción e inmoralidad», iniciado por el «libertinaje de los emperadores», que a su

\footnotetext{
31 BeLMAR: Reflexiones sobre la España..., pp. 17-23; De LA FUENTE: Historia eclesiástica de España..., vol. II, pp. 198 y 230 (cfr. II, 265: «En la monarquía goda, la Iglesia y el Estado estaban de tal manera unidos, que casi pudieran decirse identificados, si fuera dable que tales cosas pudieran llegar a identificarse. La historia no presenta otro ejemplo de relaciones tan íntimas»); MERRY y MERRY: Compendio de Historia de España..., p. 38. Ya el p. FlóreZ, en el siglo XVIII, hacía del III Concilio de Toledo el gran momento nacional (España Sagrada, V, p. 219). Cfr. AMADOR DE LoS Rıos, José: Historia crítica de la literatura..., p. 330 (Recaredo, «como Constantino, se gloriaba de aparecer cual protector de la Iglesia; [...] como Teodosio, llevaba la sinceridad de su fe hasta el punto de proclamar, cual única y exclusiva del Estado, la religión católica»); o CAvaniLles, A.: Compendio de Historia de España..., vol. I, p. 217 (Recaredo «tuvo todas las dotes que constituyen un gran rey: fe religiosa, valor, prudencia, amor a la justicia...»).
}

Hispania, LXI/3, núm. 209 (2001) 831-858 
vez había producido el desbordamiento de «las más vergonzosas pasiones del pueblo», y aplica el mismo esquema a los godos: y en especial a Witiza, que autorizó al clero a casarse, «iley abominable que revelaba por sí sola el estado de lastimosa decadencia de la civilización goda!»; «y, envilecido por el vicio, llamó, protegió y favoreció a los judíos», nuevo indicio del conflicto entre reyes y obispos; sólo el clero, insiste Merry, mantenía «su energía y religioso sentir» e increpaba al monarca ${ }^{32}$.

Pero algún efecto positivo tenía que haber dejado la constructiva tarea de Recaredo. Y éste se reveló en el hecho de que, apenas perdido el reino visigodo, comenzara la resistencia. España supo levantarse y «recobrar su nacionalidad», dice Belmar, que añade: «al sentirse el pueblo español bajo la bruma de la más ignominiosa servidumbre por haberse apartado de Dios, comprendía que sólo volviendo sobre sus pasos podía recobrar la perdida independencia»; de ahí que don Pelayo pusiera su confianza en la Virgen, y se produjera la milagrosa victoria sobre los moros. Orodea describe a Pelayo como «godo según unos, romano según otros, pero de todos modos esforzado, cristiano y español»; él dio «en los montes de Asturias el primer grito de libertad, constituyendo el momento más solemne de nuestra historia y el comienzo de nuestra civilización». Merry, por último, dice que Pelayo enardeció a algunos «tan cristianos como valientes [...] con las palabras más propias para fomentar la religiosidad y el patriotismo»: «Somos pocos y ellos son muchos, nos pelearemos por la religión y por la patria»; aquélla fue la idea «sublime y fecunda» de la civilización española en la Edad Media, pues «la religión cristiana, la patria y la lealtad son los ejes sobre los que gira la vida propia de nuestra nacionalidad en aquellos tiempos y los grandes, fecundísimos principios que prepararon la civilización gigantesca y el engrandecimiento de nuestra amada patria [...] en los poderosos reinados de Carlos V y Felipe II»33.

A don Pelayo, en efecto, siguieron las glorias de los siglos medievales. Aquélla había sido la edad dorada para los historiadores liberales, y lo era también para los católico-conservadóres, pero con matices, pues para éstos toda la gloria recaía en la lucha contra los musulmanes, y no en las libertades municipales, ni en las cortes, ni en la convivencia de culturas. Ya el padre Flórez había

32 Belmar: Reflexiones sobre la España..., p. 29; MERRY y MERRY: Compendio..., p. 24, y MERRY y COLÓN: Historia de España..., pp. 83-84. Cfr. MENÉNDEZ PELAYo, Marcelino: Historia de los heterodoxos..., I, III, XIII: Witiza, «cifra y compendio de las miserias y aberraciones morales de una edad histórica»; en su reinado "se consumó la decadencia y ruina de un florentísimo imperio». De los encontrados sentimientos de un historiador como Menéndez Pelayo ante el período godo dan idea sus últimas líneas: «los visigodos nada han dejado, ni una piedra, ni un libro, ni un recuerdo [...] y, sin embargo, icuánta grandeza en ese periodo!»; poco antes aclara que «la ciencia y el arte, los cánones y las leyes, son gloria de la Iglesia, gloria española». Sobre caídas, o salidas de situaciones descritas como paradisíacas, v. supra, cap. 4.4 .

33 Belmar: Reflexiones sobre la España..., pp. 33-35; Orodea E IBARRA: Curso de Lecciones de Historia..., p. 147; MERRY Y COLÓN: Historia de España..., p. 133,y Elementos de bistoria crítica..., p. 243. 
presentado a el Cid o Fernán González como «insignes vencedores de moros, llenos de celo por la Fe y dotadores de templos». Merry se refiere a la aparición del apóstol Santiago en Clavijo como «uno de los días de mayor gloria para la nación española»; y descarta toda duda sobre aquel milagro, arguyendo que en pleno siglo XIX el mundo entero ha sido testigo de estupendos prodigios, como el ocurrido en Lourdes. Toda esta literatura está claramente inserta en las polémicas del catolicismo del siglo XIX con el racionalismo moderno. Tras el "glorioso reinado de San Fernando", otro momento culminante del relato, se llega a la coronación de la Edad Media con los Reyes Católicos, «el período más brillante de la historia patria»; España «recobró la unidad que tuvo en tiempos de los godos. [...] Renació llena de vida la nación [...] Lanzados de nuestro territorio los sectarios del Profeta, ondeó del uno al otro mar el estandarte de la Redención. iGrande época! [...] Galería de gigantes [...] una epopeya». Otro autor llama «brillante» a «la época en que florecieron los Reyes Católicos», cuando «descollaban en España los hombres más eminentes en política, en administración, en ciencias morales, en artes nobles y mecánicas, en el comercio, en la navegación y en la milicia». Para un tercero, el reinado de Fernando e Isabel, «monarcas insignes», «tan gloriosos para la civilización española», «cuyos levantados hechos ha perpetuado la fama esculpidos en limpios mármoles y en duros bronces», se caracterizó porque los reyes fijaron su política «en la reconstitución de la nacionalidad española sobre la base de la unidad en todos los órdenes» ${ }^{34}$.

Éste de la unidad es, precisamente, y como sabemos, un tema peliagudo. Porque incluye, por ejemplo, la expulsión de los judíos. Pero Amador de los Ríos había proporcionado una explicación tranquilizadora en 1848 y la repite en su Historia crítica de la literatura española, de $1861^{35}$. Algunos, como Orodea, se conforman con esa interpretación: al igual que el arrianismo en tiempo de los godos, «la existencia de los judíos [...] destru[ía] la robusta vitalidad y las fuerzas que se derivan de la unidad religiosa». Pero la mayoría de estos autores tienden a ser menos piadosos y repiten la lista de maldades de los hebreos: sus prácticas usurarias, la terrible conspiración tramada para entregar España a los árabes, «su orgullo, su doblez, sus malas artes» 36 . Otros explican que se hizo

34 FLÓREZ: España sagrada..., XXVII, p. 245 y 799 (III, p. 116, sobre San Fernando); MERRY y Colón: Historia de España..., pp. 170-171; CAvANILles: Compendio de Historia de España..., vol. IV, pp. 273-274; FerRer DE COUTO: Crisol histórico español , p. 41; y MERRY y MERRY: Compendio de Historia de España..., pp. 132-133.

35 Pp. 330-31: en tiempos de los godos eran «raza proscrita, contra quien había lanzado ya el sacerdocio español sus anatemas; su laboriosidad, su ingenio y su osadía le habían conquistado, sin embargo, riquezas, ciencia y representación»; "celosos los padres del Concilio de la integridad del dogma [...] les declararon indignos de obtener oficios públicos», lo cual les llenó de "amargura", «despertando en su pecho profundo rencor»; la permanente conflictividad entre ambas razas «obligó» por último a los Reyes Católicos a dictar el famoso decreto de 1492.

36 Orodea E IbarRa: Curso de Lecciones de Historia..., p. 118 (repite, en pp. 305-311, términos de Amador: el pueblo hebreo, "a quien las desgracias han hecho tan acomodaticio que es el único sin nacionalidad...»); usura y conspiraciones, en MONREAL Y ASCASO: Curso de Historia de España...,

Hispania, LXI/3, núm. 209 (2001) 831-858 
necesario tomar medidas para proteger a los judíos, para evitar las «hecatombes de israelitas»; por ello habían dispuesto los reyes «que viviesen solos en sus juderías los individuos del pueblo deicida». Al fin, de todos modos, se hizo «inevitable» su expulsión y el decreto fue "recibido con júbilo por el pueblo». Hay quien explica que, aunque se les prohibió llevar consigo los metales preciosos que poseyeran, "estos desgraciados, sin patria, sin hogar y sin templo", pudieron sacar sus riquezas por medio de «letras». Monreal cree que el reino sufrió con la expulsión un golpe «bajo el punto de vista material y económico», pero «la España de aquellos tiempos obraba obedeciendo a miras nobles y elevadas». El más duro, como de costumbre, es Merry, para quien los Reyes Católicos crearon la Inquisición contra los judíos porque tenían "pruebas plenísimas y muy repetidas de que éstos trabajaban sin descanso porque abjurasen su fe los cristianos»y "planes insidiosos con los hebreos de otros reinos» ${ }^{37}$.

Intimamente ligada al tema judío, la Inquisición siempre se ve, como mínimo, disculpada. Han pasado los años desde los tiempos de los Vélez y Alvarado, que seguían identificándose con el Santo Oficio y reclamando su mantenimiento. Ninguno de estos autores lo hace. Pero sí creen que al Santo Oficio se debió «la unidad religiosa, base de la nacional», en palabras de Sánchez y Casado. Y justifican su creación, además de por los peligros políticos representados por las minorías religiosas, por las circunstancias de la época. Cavanilles observa que se habían descubierto inteligencias de judaizantes y moriscos con sus correligionarios de Granada y África; "muchas de las conversiones no eran sinceras» y a la sombra de ellas "trataban de levantar el país, y aun se creyó que habían llamado las fuerzas del turco»; en todo caso, termina, "culpemos al siglo en que tales cosas ocurrían», «recordemos que a los siglos pasados no se les debe juzgar por las ideas de los presentes». Monreal repite los mismos argumentos: «si, como toda institución, ha cometido abusos, debemos confesar que a él [el Santo Oficio] se debe la unidad religiosa que España conservó»; y antes de criticar a esta institución, deberían los extranjeros acordarse de la noche de San Bartolomé y las quemas de brujas; en todas partes hubo "cierto rigor», pero fue «resultado de circunstancias extraordinarias». Mucho menor

p. 70, y Merry y Merry: Compendio de Historia de España..., p. 34 (cfr. Merry y Colón: Elementos de bistoria crítica..., p. 167: justifica explícitamente la persecución y llama «falsa crítica» a aplicar al pasado criterios actuales; o MERRY Y COLÓN: Historia de España..., p. 84: Witiza, «envilecido por el vicio, llamó, protegió y favoreció a los judíos»).

37 Cavanilles: Compendio de Historia de España..., vol. V, pp. 25-26; MONREAL y ASCASO: Curso de Historia de España..., pp. 272-273 (repite que la aversión popular a judíos se debía a «haber contribuido a abrir las puertas de España a los musulmanes, con quienes siempre habían fraternizado'); MERRY y MERRY: Compendio de Historia de España..., p. 133 (cfr. MERRY Y COLÓN: Elementos de bistoria crítica..., III, 35-41). Cfr. SÁNCHEZ y CASADO: Prontuario de Historia de España..., p. 212 («prepotencia» y «aversión que el pueblo los profesaba» explican expulsión); y ORODEA E IBARRA: Curso de Lecciones de Historia..., pp. 305-311 (igualmente: la expulsión perjudicó «los intereses materiales de España», pero había que «aquietar a los pueblos»). 
problema plantean los protestantes, ajusticiados por Felipe II, según Sánchez y Casado, en corto número, «con razón y con aplauso del pueblo»; el peligro era más grave de lo que parecía, observa Vicente de la Fuente: «el protestantismo pasó los Pirineos y estaba ya casi aclimatado en España» ${ }^{38}$.

Frente al austracismo de los historiadores liberales, o acusación contra la dinastía Habsburgo de haber marcado el rumbo decadente del país, los nacionalcatólicos ven a los Habsburgo mayores bajo una luz excepcionalmente positiva. Felipe II, en especial, fue «uno de los más firmes defensores de la Iglesia católica $[\ldots]$ un contrapeso a la política protestante», «un gran personaje histórico». Todos los crímenes y maldades que se le han atribuído son puras invenciones: don Carlos murió por "sus propios excesos", el asesinato de Escobedo fue obra de Antonio Pérez sin ninguna intervención del rey, y en conjunto don Felipe fue un rey trabajador y aplicado, modelo de prudencia, talento y discreción. Similar línea de conducta siguió, en definitiva, toda su dinastía, pues los siglos XVI y XVII son la época preferida por estos historiadores. Sánchez y Casado, por ejemplo, reconoce que Felipe III no tendría «las prendas militares y políticas que forman un gran rey», pero estaba "dotado en alto grado de virtudes domésticas»; e incluso Carlos II fue un monarca «digno de lástima y de amor, no de odio ni desprecio. No le faltaban entendimiento ni voluntad; ningún rey ha querido más a sus vasallos, ninguno le ha rogado tanto a Dios por ellos ni ha llorado tanto sus desdichas...» Nadie gana, sin embargo, a Manuel y Antonio Merry en esta devoción por la casa de Austria, «aquellos reyes que subordinan todos su actos a la religión, que a ella someten la vida social y que se presentan a la faz del mundo como los verdaderos portaestandartes del catolicismo. Razón por la que el protestantismo y la impiedad los odia, acusando de ambicioso a Carlos I, de fanático a Felipe II»; incluso en la expulsión de los moriscos decretada por Felipe III fueron «ilusorios los daños que los escritores afectos al liberalismo suponen que vinieron a sufrir la industria, el comercio y la agricultura». También Felipe IV y Olivares fueron «dos figuras dignísimas», según los Merry; y si Cataluña se rebeló en 1640 fue porque estaba «infestada por las secretas inteligencias que la Francia sostenía con el Principado». Sólo Carlos II fue «de constitución enfermiza y carácter pusilánime», pero la gloria continuó hasta el final de esta «dinastía ilustre»39.

38 SÁNCHeZ y CASADO: Prontuario de Historia de España..., pp. 212 y 302-328; CAVANILles: Compendio de Historia de España..., vol. IV, pp. 316-319; MONREAL y AsCASO: Curso de Historia de España..., p. 268; DE LA FUENTE: Historia eclesiástica de España..., vol. V, p. 224.

39 De La FuENTE: Historia eclesiástica de España..., vol. V, pp. 230-231 (cfr. 340: «España, en una lucha titánica de treinta años, agotó sus hombres, sus fuerzas, sus tesoros y su industria en defensa del catolicismo"); MERRY y MERRY: Compendio de Historia de España..., pp. 146, 163, 168174, 181 y 190-193; SÁNCHEZ Y CASADO: Prontuario de Historia de España..., pp. 304-328, 347 y 377-378. Es curiosa la ausencia del tema comunero, que tan importante es para la historiografía liberal. En general, tienden a evitarlo; y en la medida en que su mención es necesaria, no muestran grandes simpatías hacia los rebeldes. V., p. ej., FERRER DE COUTO: Crisol histórico español , pp. 175-

Hispania, LXI/3, núm. 209 (2001) 831-858 
El contrapunto de los Habsburgo son los Borbones, y también aquí se revelan radicales diferencias con los liberales. Alguno de los historiadores que estamos siguiendo, como Sánchez y Casado, conserva, al marcar sus distancias respecto de la nueva dinastía, cierta cautela: con Felipe V la política y los principios de Richelieu y Luis XIV «se implantan en España con todas sus ventajas e inconvenientes" y se entra en ciclo de reformas que "prepara el de las revoluciones que llenan nuestro siglo y que no han renovado el modo de ser de la nación sino para viciarle y pervertirle». Otros, como el propio Menéndez Pelayo, expresan su disgusto ante el siglo XVIII en el título mismo con que inician la descripción del período: "Advenimiento de la dinastía francesa». Igual que los liberales habían acusado de extranjero al absolutismo de los Habsburgo, el gran teórico del nacional-catolicismo hace lo propio con la dinastía que les sucedió en el trono: «ijamás vinieron sobre nuestra raza mayores afrentas!», sigue este autor; generales extranjeros guiaban nuestros ejércitos, el palacio se vio invadido por una «plaga de arribistas extranjeros», la Iglesia se vio «atropellada en sus inmunidades por los servidores del duque de Anjou» ${ }^{40}$.

Otros, como los Merry, sueltan su agresividad de manera que raya en lo insolente, sobre todo si se tiene en cuenta que se están refiriendo a la dinastía reinante en el momento en que escriben: «La raza de los Borbones da principio a su reinado en España [...] y al empuñar el cetro Felipe $V$ sus vasallos comprenden que la política española genuinamente cristiana había pasado», pues «apoyándose sofísticamente en la distinción de la política y la religión, sólo se cuidaron de los intereses materiales» y quisieron someter a su autoridad a la Iglesia y «humillar a las clases elevadas, realzando a la vez a hombres bajos de quienes pudieran servirse a su capricho" y "quitar a los pueblos sus franquicias». Carlos III, «tan aplaudido por el liberalismo como celebrado por la masonería», era un rey personalmente piadoso, pero "trocó la monarquía de ultraregalista en revolucionaria y atrajo sobre España la decadencia más lamentable» al olvidar «los intereses morales, que son los que dan firmeza y estabilidad a la grandeza de los pueblos»; «su indiscrección abrió a la revolución las puertas del reino". La expulsión de jesuitas, a quienes se dio un plazo de veinticuatro horas y ninguna facilidad para transportar sus bienes, fue mucho más cruel que la de los moros y judíos. Los Merry, con toda nitidez, están mucho más interesados por defender los privilegios eclesiásticos que el reforzamiento del Estado español. Sólo en este tema se permiten criticar a los propios Reyes Católicos, que, según ellos, se «excedieron» en su defensa de las regalías de la coro-

181: alegaban los comuneros «no sé yo qué tiranías y arbitrariedades cometidas por el señor rey Don Carlos I»; pero «el alzamiento no fue tan unánime y general como muchos lo suponen». «Carecían de un hombre que supiera organizar la Nación...», dice MONREAL y AsCASO (Curso de Historia de España..., p. 311) y hubo muchos «errores de sus jefes, de los cuales fue el mayor el haberse enajenado a la nobleza [con] tendencias inoportunas a despojarla de sus privilegios».

40 SÁnchez y CaSAdo: Prontuario de Historia de España..., p. 386; MENÉndez Pelayo: Historia de los beterodoxos..., VI, I.

Hispania, LXI/3, núm. 209 (2001) 831-858 
na. También Belmar menciona, cuando trata de los derechos de la Iglesia, los «dolorosos desaciertos de algunos de sus reyes [de España], como sucedió en tiempos de Carlos I, de Felipe II y de Carlos III» ${ }^{41}$. El tema del regalismo recuerda al de los visigodos cuando eran arrianos: hay veces en que el héroe colectivo, la España idealizada del relato, choca con la Iglesia; el corazón del historiador nacional-católico se encuentra, en esa situación, dividido; es duro optar entre dos madres; pero, en último extremo, acaba optando por la Iglesia, antes que por España.

Transcurrido ya el odiado siglo XVIII, la epopeya nacional culmina con la sublevación contra las tropas napoleónicas. Y aquí la coincidencia con la historiografía liberal es completa, salvo en la insistencia de estos autores en subrayar el papel de la Iglesia en el levantamiento y las motivaciones religiosas del pueblo sublevado. Como dice Sánchez y Casado, «el levantamiento no fue obra de los reyes, presos en Francia, ni de los consejos, sumisos y condescendientes con el invasor, ni de las clases ilustradas, de las cuales salieron los afrancesados, sino del verdadero pueblo español, dirigido e impulsado por el clero». Nocedal, en un escrito más académico que político, también lo había dicho: «se levantó la nación por su Dios, por su Rey y por su Patria» ${ }^{42}$.

Toda la historia estaba dirigida a demostrar, por tanto, que la nacionalidad española había sido formada por la religión católica. Fue una religiosidad innata, casi desde antes de que se predicara el cristianismo, y ha durado hasta la última gran hazaña, frente a Napoleón. Como escribe Sánchez y Casado, «tres son los caracteres del pueblo español que aparecen en todo el curso de nuestra historia, constituyendo su fisonomía especial y el resorte de todos sus grandes acontecimientos: el sentimiento religioso, sin el cual España hubiera dejado de ser nación, como la Siria, el Egipto y la Berbería; el amor a la patria, por cuya independencia pelearon nuestros antepasados dos siglos contra los romanos, uno contra los godos y ocho contra los árabes; y, en fin, la monarquía, que nos ha dado caudillos en la guerra, sabios que se adelantaron a su siglo, políticos consumados». Y los Merry anuncian, al iniciar su libro, que pretenden purgar «nuestra historia de la serie de errores con que el protestantismo, el filosofismo y el racionalismo han pretendido oscurecer nuestras glorias nacionales, que en

41 MERry y Merry: Compendio de Historia de España..., pp. 181-182 y 190 (cfr. AMADOR DE Los Ríos, Juan F.: España en las edades moderna y contemporánea, Pamplona, 1912, p. 132: aunque personalmente fuera «devoto ferviente», «para la Iglesia fue realmente tiránico el gobierno de Carlos III»); MERRY y COLÓN: Elementos de bistoria crítica..., III, p. 41y ss.; y BeLMAR: Reflexiones sobre la España..., pp. 583-584.

42 SÁNCHeZ y CASAdo: Prontuario de Historia de España..., pp. 484-485; NOCEDAl, Cándido: «Discurso preliminar» a las Obras de JovellaNOs, Gaspar Melchor, Madrid, 1858, p. XXXIII. Cfr. GEBHARDT, Víctor: Historia general de España y de sus Indias, 7 vols., Barcelona, 1861-64, vol. 6, cap. XIV, p. 468; MERrY y MERRY: Compendio de Historia de España..., p. 205 (comparación de 1808 con Covadonga); y AMADOR DE LOS Ríos, Juan F.: España en las edades..., p. 2 («movimiento de frailes, curas, estudiantes, militares y de todas las clases sociales...").

Hispania, LXI/3, núm. 209 (2001) 831-858 
tanto han sido grandes y múltiples en cuanto fueron eminentemente católicas»; «en la unidad católica se halla el fundamento de nuestra magnificencia de pasados siglos» ${ }^{43}$.

España se inscribe, pues, en «defensa del catolicismo» de una manera natural, sencilla. Es la defensora del catolicismo (y la civilización) frente a ideologías disolventes de la modernidad. En estas expresiones se funde el nacionalismo de inspiración católica con la mentalidad, tan propia del catolicismo del XIX, de resistencia ante el asedio de la modernidad. España sobrevive y es fiel a sí misma, aguantando los embates de la incomprensión extranjera, como los papas, encerrados en el Vaticano, resisten a las oleadas del materialismo racionalista. El verdadero objetivo de alguno de estos libros es fundir ambas causas: Belmar, más que nadie, explica cómo España ha defendido siempre la soberanía temporal del papa y cómo ello no hace sino responder al orden natural del universo, pues «el Omnipotente ha colocado en el firmamento del cielo [...] dos grandes luminarias [...] dos dignidades supremas: la autoridad pontificia y la potestad real»; «si quitáis sus rayos al astro del día [Iglesia] nada debéis prometeros del astro de la noche» ${ }^{44}$. Era una manera de presentar a España que la obligaba a seguir empleando su ejército como garante de lo que quedaba de territorios papales frente a los nacionalistas italianos.

La incompatibilidad entre esta versión de la historia y la de los liberales era clara. Ambas coincidían en la vertebración del relato de acuerdo con la clásica secuencia mítica de Paraíso-Caída-Redención, y en los dos casos el paraíso había sido netamente «español» mientras que la salida del mismo se había debido a nefastas influencias extranjeras. Pero las etapas históricas a las que estas fases míticas se referían, y los valores éticos y politicos anexos a las mismas, variaban. Para los liberales, la edad de oro se situaba en la Edad Media y estaba simbolizada por las libertades forales y el juramento regio ante las cortes aragonesas, desaparecido todo bajo el yugo de los Habsburgo; lo que quería decir que su propuesta de redención o retorno a la era feliz consistía en la afirmación de la soberanía nacional y los derechos individuales. Para el conservadurismo católico, el paraíso hispano se había vivido bajo Carlos V y Felipe II, con los

43 SÁnChez y CASAdo: Prontuario de Historia de España..., p. 2; Merry y Merry: Compendio de Historia de España..., "Al lector». Merry comienza sus tres libros criticando a autores liberales, empezando por el francés Romey (que «no perdona ocasión para ensañarse con nuestras glorias nacionales por lo que tienen de eminentemente católicas»), pero también al propio Modesto Lafuente (que cae en los «errores» de José A. CONDE, en su obra de 1820 Historia de la dominación de los árabes...), o a Cavanilles, Antonio, que aquí clasificamos como precursor del nacional-catolicismo y que para él está, junto con Alberto Lista, «saturad[o] del espíritu liberal», que «respiran saña contra el catolicismo y las veneradas tradiciones españolas»; en sentido contrario, considera «espíritu sinceramente católico e imparcial», que vindica «nuestras glorias», a Víctor Gebhardt, en nuestra opinión un autor ecléctico (v. MERRY y COLÓN, Historia de España..., p. 18).

44 BeLMAR: Reflexiones sobre la España..., p. 31; cfr. pp. 51 y 59: «las dos antorchas del mundo, el sacerdocio y la reyecía»; los reyes, «vice-gerentes del Altísimo en el gobierno de la sociedad». 
teólogos de Trento y la victoria de Lepanto; la salida de aquel paraíso se había debido a reyes «débiles» y a imitación de modelos ilustrados. Lo que también dejaba traslucir con claridad su programa político: unidad política, por encima de la libertad, y monolitismo católico.

Al finalizar el siglo XIX, tras largos y complicados meandros, la derecha española había completado el proceso de aceptación del nacionalismo, fundido ya con el catolicismo. "Apenas podemos distinguir a la Iglesia católica y a la nación española», confesaba, con ingenua franqueza, El Siglo Futuro en 1892. No era casual que Menéndez Pelayo, el hombre que puso la última piedra del edificio, fuera un gran admirador de Balmes, padre de la idea, y que no le gustara, en cambio, Donoso, que planteaba la contrarrevolución en términos católicos o europeos. Con razón don Marcelino conceptuaba a Donoso de poco español, dotado de una "palabra deslumbradora, con cuyo regio manto revistó alternativamente ideas bien diversas, todas de purísimo origen francés». También Alejandro Pidal, el dirigente de la Unión Católica, reconocía tener una «repulsión espontánea y nativa» por Donoso, mientras que por Balmes sentía un «entusiasmo reflexivo pero avasallador». Y es que Balmes había puesto la primera piedra, los neo-católicos habían continuado el edificio y Menéndez Pelayo lo había coronado. Los capítulos siguientes, ya no de creación sino de expansión de la idea, correrían a cargo del tradicionalista Vázquez de Mella o del cardenal Merry del Val — pariente de aquellos Merry historiadores destacados por su versión extremadamente católica del pasado nacional-, inspirador de las grandes movilizaciones católicas de la era de Pío X. Bajo la égida de Merry del Val, al comenzar el siglo XX, surgió la Acción Católica, emanación de los «Congresos católicos» que se celebraron entre 1889 y 1902, y que, a su vez, habían sido continuación de aquellos centenarios en que había culminado el neo-catolicismo en los años ochenta. De miembros de la Acción Católica se nutrirían las filas de la Unión Patriótica de Primo de Rivera en los años veinte y, sobre todo, las de la CEDA en los treinta. Los dirigentes e ideólogos de la movilización católica serían ya, por entonces, los arzobispos Gomá o Pla y Deniel, grandes personajes del régimen victorioso en la Guerra Civil. Pedro Sáinz Rodríguez, primer ministro civil de Educación nombrado por Franco, proclamó a Menéndez Pelayo, en plena guerra, base doctrinal del sistema educativo que el nuevo régimen iba a implantar para regenerar el país ${ }^{45}$.

45 MenÉndez Pelayo: Crítica literaria, Santander, 1942, t. V, pp. 214-215; PIDAl, Alejandro: Balmes y Donoso Cortés. Orígenes y causas del ultramontanismo, en Ateneo. Conferencias históricas, Madrid, 1887, t. III, p. 253. Sobre Vázquez de Mella, v. LAFAGE, Franck: L'Espagne de la contrerévolution..., cit., pp. 173-75. Sobre Merry y el movimiento católico, MONTERO, Feliciano: El movimiento católico en España, Madrid, 1993, pp. 28-41. En la relación entre Menéndez Pelayo y el franquismo hay, desde luego, una diferencia importante en todo lo relativo con la centralización o el "estatismo" del régimen de 1939, contrario a la visión "austracista» del pensador santanderino, como observa en CaPestany, E. J.: Menéndez Pelayo..., p. 39.

Hispania, LXI/3, núm. 209 (2001) 831-858 